\title{
A corpus-based study of the human impersonal pronoun ('n) mens in Afrikaans
}

Compared to men and een mens in Dutch ${ }^{1}$

\author{
Daniël Van Olmen, Adri Breed, Ben Verhoeven \\ Lancaster University (United Kingdom), North-West University \\ Potchefstroom (South Africa), University of Antwerp (Belgium)
}

This article compares the grammaticalizing human impersonal pronoun ('n) mens in Afrikaans to fully grammaticalized men and non-grammaticalized een mens in Dutch. It is shown that 'n mens and een mens can still be used lexically, unlike mens and men, and that ('n) mens and een mens are restricted to non-referential indefinite, universal-internal uses while men exhibits the whole range of (non-)referential indefinite ones. Despite the latter's presence in the earliest Afrikaans data, it is argued not to have influenced the development of ('n) mens. This pronoun and Dutch een mens are also found to have syntactic functions other than subjecthood, unlike men. The contrast is attributed to their different degrees of grammaticalization. Lastly, the Afrikaans 'man'-pronoun is shown to differ from its Dutch counterparts in relying on the second person singular for suppletion, though forms of ('n) mens are found to occasionally occur instead.

Keywords: grammaticalization, impersonal, pronoun, Afrikaans/Dutch

\footnotetext{
${ }^{1}$ Earlier versions of this paper were presented at the Germanic Sandwich workshop at the University of Nottingham in April 2015, the Workshop on R-Impersonals at the Friedrich Schiller University Jena in September 2015 and the Ghent Colloquium Afrikaans at Ghent University in October 2015. Thanks are due to the Centre for Text Technology at the North-West University, Hendrik De Smet, Volker Gast, Jacques van Heerden and Johanita Kirsten, as well as the workshop participants who gave us invaluable feedback.
} 


\section{Introduction}

The last 15 years have seen an increasing interest in human impersonal pronouns (HIPs). They can be defined as the pronominal expression of impersonalization, "the process of filling an argument position of a predicate with a variable ranging over sets of human participants without establishing a referential link to any entity from the universe of discourse" (Gast and van der Auwera, 2013: 124). English one in (1) is a case in point. ${ }^{2}$

(1) One can't learn a language in six weeks.

HIPs have been studied quite extensively in European languages (e.g. Egerland, 2003) and particularly West Germanic (e.g. Weerman, 2006). Afrikaans, however, has not received much attention, except in Kirsten (2016: 189-201) - despite, for instance, the fact that it is developing a new HIP based on the noun for 'human', i.e. ('n) mens '(a) human'.

For that reason alone, Afrikaans, and especially ('n) mens, merits closer examination. What also makes ('n) mens interesting is that the indefinite article ' $n$ is optional. This phenomenon is actually commented on in our data, as (2) shows.

Afrikaans

In 'n paar gevalle is die Afrikaans vir ons 'n bietjie plat. Dit geld veral die weglating van die lidwoord "' $n$ " in sinne als:

$\begin{array}{lllllll}\text { 'Wat moet ['n] } & \text { mens } & \text { sê } & \text { vir die meester as ['n] } \\ \text { what must a } & \text { human } & \text { say to the teacher if a }\end{array}$

mens weg wil gaan?' (Historical Corpus Afrikaans, 1917)

human away want go

"In a few cases, Afrikaans is slightly too common for us. This is especially true of the omission of the article ' $n$ in sentences like: 'What should one say to the teacher when one wants to leave?"'

Giacalone Ramat and Sansò (2007: 102) point out that, in European languages, many nouns meaning '(hu)man' lost their articles when becoming HIPs. The fact that ' $n$ can but need not be expressed signals the ongoing grammaticalization of the new 'man'-pronoun in Afrikaans. In this article, we seek to examine this grammaticalizing HIP from the perspective of a fully grammaticalized one. The obvious candidate is Dutch men. Not only has men lost its article completely and been reduced phonetically to [mon], it is also the predecessor of ('n) mens. The last attestations of men in our Afrikaans corpora date from the 1910s. They typically occur in texts written in a variety with many Dutch-like features, however. The inflected verb form heeft 'has' in (3a) is an example: as in (3b), Afrikaans normally uses het 'have/has',

\footnotetext{
${ }^{2}$ All examples without a reference have been created by us. We have also translated all examples ourselves (as well as a few quotations from a secondary source originally written in Afrikaans). For reasons of space, only the relevant parts of the examples in Section 1 have word-for-word glosses, which should make the systems of Afrikaans and Dutch clear to readers unfamiliar with the languages. Note that men has been glossed as 'man', the lexical item from which it derives.
} 
which is vague in person and number.

(3) Afrikaans

a. Indien men geen boter bij die hand heeft gebruik if man no butter at the hand has use

men soet olie. (Historical Corpus Afrikaans, 1917)

man sweet oil

"If one doesn't have butter at hand, one uses sweet oil."

b. Maar ' $n$ mens het nou en dan behoefte daaraan

but a human have now and then need there.for

om jou hart uit te praat. (Historical Corpus Afrikaans, 1915)

to your heart out to talk

"But, once in a while, one has the need to pour one's heart out."

Intriguingly, Dutch can employ een mens 'a human' in impersonal contexts like (4) too. Unlike its Afrikaans counterpart, though, it is not grammaticalizing. The indefinite article, for instance, cannot be omitted.

(4) Dutch

Ik kan er niet alles mee wat ik wil maar een[/* $\emptyset]$

I can there not everything with what I want but a

mens kan niet alles hebben. (ConDiv)

human can not everything have

"I can't do everything I want with it but one can't have it all."

Moreover, unlike ('n) mens in (5a) (and men), een mens cannot be followed by reciprocal pronouns, as (5b) shows. Its reference is necessarily singular rather than entirely arbitrary (cf. Weerman, 2006: 29). In this study, we also aim to look at the grammaticalizing Afrikaans HIP from the perspective of its non-grammaticalized Dutch cognate.

(5) a. Afrikaans

('n) Mens moet mekaar help.

a human must each.other help

"One should help each other."

b. Dutch
*Een mens
moet elkaar helpen.
a human must each.other help
"One should help each other."

More specifically, our article seeks to answer the following questions. First, does 
grammaticalizing ('n) mens increase in frequency over time, as may be expected? Second, does the more grammaticalized form mens gain ground on ' $n$ mens? Third, does ('n) mens differ in its functions from fully grammaticalized men and nongrammaticalized een mens in Dutch and, if so, how? Fourth, are there any formal (dis)similarities between all these items and, if so, which ones? Fifth, how do (' $n$ ) mens and men compare to other 'man'-pronouns? The first two questions are primarily concerned with Afrikaans. The remaining ones contrast Afrikaans to Dutch and other languages.

It is important to note that some of these issues have been addressed independently by Kirsten (2016: 190-193). As our study relies on the same diachronic corpus, it will replicate some of her results. They include men's occurrence in the Afrikaans data and mens's frequency versus 'n mens over time. Kirsten's (2016) findings will obviously be referred to when necessary. There are crucial differences between her work and ours, though. First, the examples and numbers of her functional analysis suggest that she has looked at mens in all possible environments. Our focus is on ' $n$ mens and bare mens (see Section 2.2). Second, Kirsten (2016) does not compare the uses of mens and 'n mens or contrast Afrikaans to Dutch. Third, to draw such comparisons, our analytic framework is slightly more fine-grained than hers (see Section 3.1). Fourth, the formal issues of suppletion and syntactic functions (see Sections 4.2 and 4.3) receive no attention in Kirsten (2016).

In the following, we will first discuss our methodology, in Section 2. Section 3 will then concentrate on the functional aspects of ('n) mens, men and een mens. In Section 4, we will examine their formal aspects. Section 5 is the conclusion, in which the Afrikaans and Dutch 'man'-pronouns will be compared to their equivalents in other languages.

\section{Methodology}

\subsection{Corpora}

A study of the history of ('n) mens requires a diachronic corpus. To our knowledge, only one such corpus exists. For her research into grammatical changes in the language, Kirsten (2016) compiled a corpus of 20th- and 21st-century Afrikaans. It is made up of data from 1911-1920 and every third decade after that. For each period, she collected a set of extracts of 2,000 words apiece. The four sets are comparable in size (about 260,000 words) and contain the same text types (fiction, popular nonfiction, academic prose and unpublished material) in similar proportions (see Kirsten, 2016: 65-71). The design of this Historical Corpus Afrikaans will allow us to map any changes in ('n) mens with relatively high confidence.

Two more corpora of Afrikaans will be employed here. The first one is a large collection of 1990 and 2000 articles from the newspaper Die Burger (De Smet, n.d.). These data will be drawn on to check, in a sizeable corpus, for any increase in the use of mens in contemporary Afrikaans. The second one is the Taalkommissiekorpus, a substantial corpus of present-day written language (Taalkommissie, 2010). It consists of newspapers, magazines, academic texts, fiction and non-fiction books and will be used to explore (dis)similarities between text types in the choice between ' $n$ mens 
and mens.

For the comparison with Dutch, we will rely heavily on the extensive literature on Dutch men (e.g. Coussé and van der Auwera, 2012; Draye, 2014). It covers its formal and functional behavior in more than adequate detail for our purposes. Yet, we will draw on ConDiv too (Grondelaers et al., 2000), a sizeable corpus of written Dutch from the 1990s with newspaper articles and email and chat conversations. It will mainly be employed to exemplify our claims about men and take a closer look at the usage of een mens. We are aware that this corpus is not strictly comparable to (the 21 st-century part of) the Historical Corpus Afrikaans. However, both contain a range of genres varying in degrees of formality and editing (Grondelaers et al., 2000: 357358; Kirsten, 2016: 65-68). Each can be assumed to give a fairly good idea of current writing in its language. This resemblance is sufficient here: our study does not aim to provide an exhaustive quantitative comparison of usage patterns in Afrikaans and Dutch.

\subsection{Data retrieval}

From the Historical Corpus Afrikaans, we extracted all attestations of mens. Any hits not featuring bare mens or ' $n$ mens were filtered out manually. We left out, for example, cases of mens preceded by other determiners and of ('n) mens modified by adjectives, like (6a) and (6b). As mentioned in Section 1, such instances do seem to be included in Kirsten's (2016: 191) analysis. Their exclusion here is motivated by our focus on the structures that actually function as a HIP or are identical in form and may, as such, offer insight into the development of impersonal ('n) mens. The attestations in (6), for instance, are formally different from the HIP and do not span over sets of human participants without creating a referential connection to any discourse entity: the lexical meaning of 'human being' is still present and/or a type of person is specified.

(6) Afrikaans

a. Want dit is iets wat elke mens nodig het.

(Historical Corpus Afrikaans, 1973)

"Because this is something each human being needs."

b. Jy moet self oud wees om 'n ou mens te kan verstaan.

(Historical Corpus Afrikaans, 1943)

"You have to be old yourself to be able to understand an elderly person."

In (7), an example is given warranting the inclusion of all structures identical to the HIP: ' $n$ mens can be understood as referring to mankind here but can be interpreted impersonally too, as 'one'.

(7) Afrikaans

Sonder geloof kan ’n mens God nie behaag nie.

(Historical Corpus Afrikaans, 2007)

"Without faith, man/one cannot please God." 
This context - negation, modality and some contrast to God - may thus be one of the environments from which the 'man'-pronoun in Afrikaans arises.

The other corpora of Afrikaans will be drawn on primarily to study the variation of ' $n$ mens with mens. Because of their size, the fact that ('n) mens can be a HIP as in (2), an indefinite NP as in (8a) and (8b) or ambiguous between the two as in (7) poses a problem.

Afrikaans

a. 'n Mens wie se kop reg aangeskroef is, weet wat hy kan vertel en wat nie.

(Historical Corpus Afrikaans, 1975)

"A person whose head is screwed on right knows what he can and cannot say."

b. Toe mens en dier nog in 'n geskokte toestand was...

(Historical Corpus Afrikaans, 1971)

"When man and beast were still in a state of shock..."

Cases like (8a), in which ' $n$ mens cannot be replaced by mens, should not be taken into account. It would be impossible, though, to check every hit and disentangle the ones with a HIP interpretation from the countless other ones. We therefore focused on one easily searchable context that has been argued to typically trigger an impersonal interpretation, i.e. modal verbs. Gast and van der Auwera (2013: 141), for instance, consider modal clauses a specific node on their semantic map of HIPs. Giacalone Ramat and Sansò (2007: 101) argue that non-assertive environments like modal ones constitute the contexts in which 'man' comes to function as a HIP (see also Section 3.2). We extracted all attestations of the Afrikaans modals (e.g. kon 'could', mag 'may'; for the entire list, see Conradie, 2017) immediately preceded or followed by mens or ' $n$ mens and compared the frequencies of the two forms. ${ }^{3}$

From ConDiv, we retrieved all Northern Dutch attestations of men and een mens. The Belgian Dutch component was excluded purely to manage the amount of information. From the 10,141 hits for men, a random sample of 200 relevant instances was extracted. The same was done for the 368 hits for een mens. These samples will allow us to ground our examination of grammaticalizing (' $n$ ) mens in light of grammaticalized men and non-grammaticalized een mens in usage data, on top of the existing literature.

\subsection{Statistics}

To answer the question whether ('n) mens increases in frequency over time, we will first normalize its raw numbers of instances into relative frequencies per 10,000 words. Following Gries (2013), we will then compute a Kendall's tau correlation coefficient in $\mathrm{R}$. This test checks whether changing relative frequencies in a number

\footnotetext{
${ }^{3}$ Supporting evidence comes from the Historical Corpus Afrikaans's 2001-2010 component. All hits for mens followed or preceded by a modal serve as HIPs. Of the attestations of ' $n$ mens collocating with a modal, $94.92 \%$ have an impersonal interpretation. These figures suggest that our approach to the other corpora will probably overestimate the number of HIP instances of ' $n$ mens only slightly.
} 
of periods correlate significantly with progressing or "increasing" time. The advantage of Kendall's tau is that, unlike other correlation coefficients, it makes no assumptions about the distribution of the data (Gries, 2013: 375-379). The test generates a $\tau$ value - from -1 to 1 , indicating a strong negative to a strong positive correlation - as well as a $\mathrm{p}$ value.

To compare specific periods in the Historical Corpus Afrikaans (rather than evaluate an entire frequency evolution over time), we will employ Rayson and Garside's (2000) log-likelihood calculator. ${ }^{4}$ This test has been designed specifically for the comparison of raw frequencies across corpora of potentially dissimilar sizes. It produces a $\mathrm{G}^{2}$ value, which points to a significant difference when higher than 3.84 $(\mathrm{p}<0.05)$ and a highly significant one when higher than $6.63(\mathrm{p}<0.01)$.

Lastly, to find out whether ('n) mens evolves functionally and whether mens gains ground on ' $n$ mens, we will follow Gries (2013: 367-371) and do Pearson's chisquared tests in R. They will tell us whether the different proportions of impersonal versus non-impersonal ('n) mens or of the presence versus absence of the article - the categorical dependent variables - in the components of the Die Burger Corpus, the Taalkommissiekorpus and the Historical Corpus Afrikaans - the independent variables - are a matter of chance or not. The test gives us a $\chi^{2}$ value and a corresponding $\mathrm{p}$ value.

\section{Functional analysis}

\subsection{Analytic framework}

The attestations of ('n) mens, men and een mens are analyzed in terms of the uses of 'man'-pronouns identified by Giacalone Ramat and Sansò (2007: 99-106) and, when necessary, the extra distinctions made by Siewierska and Papastathi (2011: 604) and Gast and van der Auwera (2013: 141). In the first use, also from a diachronic perspective, the form still functions as a noun and has the meaning 'human being', as in (9). It corresponds roughly to Kirsten's (2016: 191) "noun” use.

(9) Afrikaans

'n Mens se kop is heel wat groter [as 'n skaap se kop], dus sal ' $n$ mens mos meer harsings hê.

(Historical Corpus Afrikaans, 2008)

"A human's head is much bigger [than a sheep's head], so a human will have more brains."

In generic contexts like (10a) and (10b), this nominal use is understood as referring to all humans or, put differently, as 'human race, man(kind)'. In Kirsten's (2016: 191 in translation) framework, such cases belong to the separate category of "mankind", which she illustrates with (10c), because they "form a bridge to an even more abstract, grammatical use ... as a generic pronoun".

(10) a. Dutch

Hoe kan een mens zich vrij weten als hij zichzelf geen enkele wezenlijke

\footnotetext{
${ }^{4}$ See http://ucrel.lancs.ac.uk/llwizard.html [last accessed on 6 October 2017].
} 
waarde toekent?

(ConDiv)

"How can man consider himself to be free if he attributes no essential value to himself?"

b. Afrikaans

Hier sien ons wat 'n mens kan doen als hij wil.

(Historical Corpus Afrikaans, 1912)

"Here, we see what man can do if he wants to."

c. Afrikaans

Die mens met sy beperkte en verduisterde vermoëns is ook soeker na skoonheid.

(Historical Corpus Afrikaans, 1971)

"Man with his limited and obscured abilities is also a searcher for beauty."

Kirsten (2016) is right in pointing out that instances meaning 'man(kind)' can be a stepping stone toward a HIP use: the interpretation of the NP in, say, (10b) comes close to impersonal 'what one can do if one wants to'. However, the optionality of the indefinite article in ('n) mens suggests that her particular example, with the definite NP die mens 'the human', cannot be the direct source of the Afrikaans 'man'pronoun. In addition, it is important to note that een mens and ' $n$ mens do not yet serve as HIPs in (10a) and (10b). Unlike full-fledged 'man'-pronouns, they are referred back to by the third person singular pronoun hij 'he'. Men does not allow this type of anaphoric reference, as (11) shows (see also Giacalone Ramat and Sansò, 2007: 109-111).

(11) Dutch

Men hoort zijn vrouw mee te nemen als $m e n / * h i j$ uitgaat.

(ConDiv)

"One is supposed to bring along one's wife when one goes out."

For that reason, (10a) and (10b) are still regarded as instances of the noun with the meaning 'human being' here. The cases in Kirsten's (2016) "mankind" category that are truly ambiguous between a noun and a HIP are analyzed as such.

In the second use, which constitutes the initial step in the grammaticalization of 'man'-pronouns, the form is understood as "a human non-referential indefinite element” (Giacalone Ramat and Sansò, 2007: 101). It corresponds to Kirsten's (2016: 191) "generic pronoun" category. In (12a), the speaker is making a general claim not about all humanity but a contextually delineated subset of it. They are also not referring to a specific person or group of people. The existence of a (set of) individual(s) going for a walk is not implied. This use can be paraphrased as (any)one and is often called "(quasi-)universal" (Gast and van der Auwera, 2013: 138). Importantly, Giacalone Ramat and Sansò (2007: 102) observe that 'man' as a nonreferential indefinite can occur without an article in many languages. Afrikaans is one of them, as (12b) shows.

(12) Afrikaans 
a. Als 'n mens op die strand 'n wandeling gaan neem moet jij jou kleë of jij in Adderley Straat loop.

(Historical Corpus Afrikaans, 1918)

"If one goes for a walk on the beach, one is supposed to dress as if one is walking in Adderley Street."

b. Mens moet maar jou skoolgeld betaal.

(Historical Corpus Afrikaans, 2004)

"One can only learn from hardship." (literally "One should pay one's tuition.")

Another feature signaling the HIP status of ('n) mens in particular here is the compulsory use of second person singular forms to refer back to it (see Donaldson, 1993: 139-140) - rather than third person singular masculine ones, as in (10b). In (12a), ' $n$ mens is replaced by the subject pronoun $j i j$ 'you' in the main clause. In (12b), mens is followed by possessive jou 'your'.

Two further uses of 'man'-pronouns, each of which has been argued to arise from the non-referential indefinite use, are a human referential definite and a human referential indefinite one. In the referential definite one, the speaker uses 'man' to refer to a known specific (set of) individual(s), typically themselves with or without a second person (see Giacalone Ramat and Sansò, 2007: 104). This use is paraphrasable as $I$ or we. In a context like (13a), for instance, a reading of ' $n$ mens as a reference to solely the speaker is perhaps not entirely impossible. In the referential indefinite use, the speaker has a specific person or group of people in mind but is unable/unwilling to identify them more accurately: in (13b), the existence of a particular (set of) individual(s) having thwarted the CD is implied but it is not made clear exactly who they are.

\section{a. Afrikaans}

Ek mis jou vreeslik en verlang baie na jou, ag, hoe sal dit tog gaan wanneer ons maande lank van mekaar sal wees? 'n Mens wil liewer nie te veel daaraan dink nie.

(Historical Corpus Afrikaans, 1949)

"I miss you tremendously and really long for you, oh, how will things go when we'll be separated from each other for months? I/one prefer/s not to think about that too much."

b. Dutch

De democratie in ons land is naar een schrikbarend laag niveau teruggeschroefd. Men heeft niets nagelaten ... om de CD te dwarsbomen.

(ConDiv)

"The democracy in our country has been reduced to a terrifyingly low level. They have taken every opportunity ... to thwart the CD."

This use can be paraphrased as some people or someone and is often called "existential" (Gast and van der Auwera, 2013: 140).

3.2 Results for Afrikaans 
Figure 1 gives an overview of our functional analysis of all attestations of ('n) mens in the Historical Corpus Afrikaans. It presents, for each period, the raw numbers and proportions of the different uses of ' $n$ mens and mens separately and together.

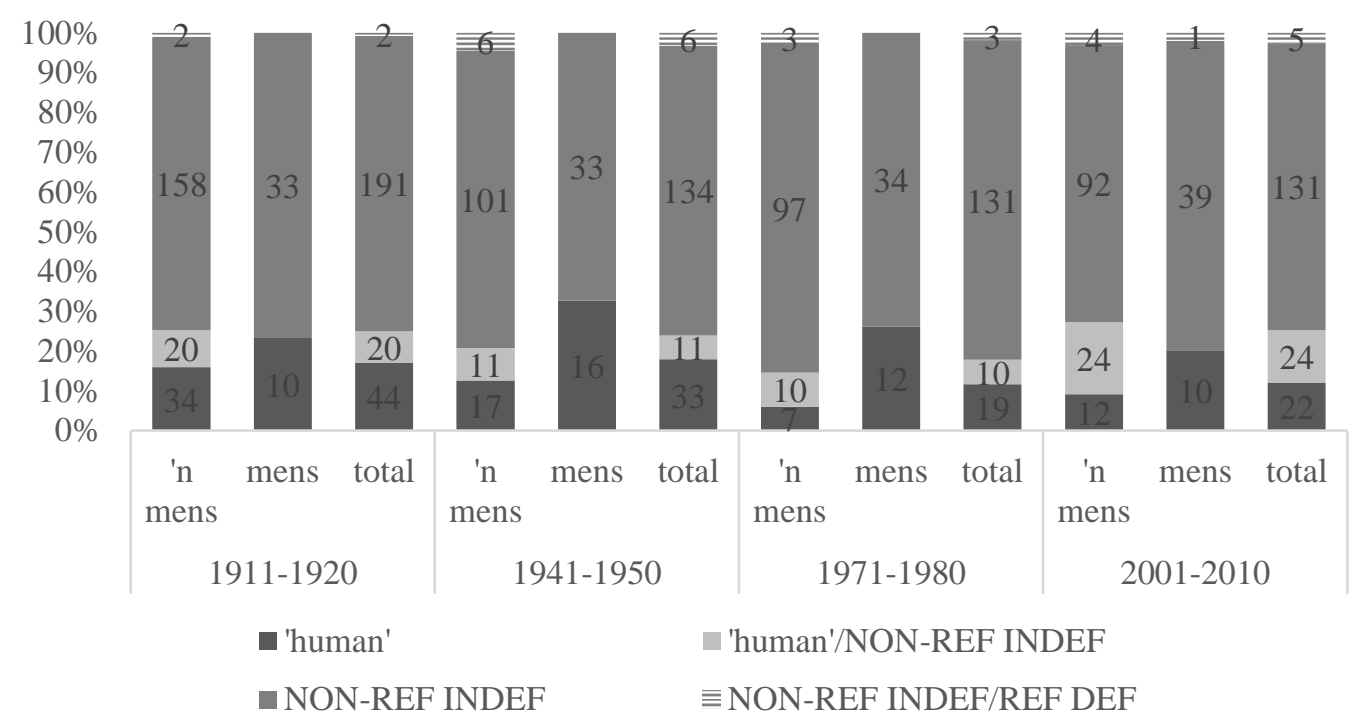

Figure 1. Functional analysis of ('n) mens in the Historical Corpus Afrikaans.

Note also that all attestations were initially analyzed by the first two authors independently. Disagreements were settled through discussion afterward.

A first observation concerns the uses of ' $n$ mens versus mens. A quick look at Figure 1 suggests that the two forms are very similar in their functional range. This impression is corroborated by the statistics. ${ }^{5}$ The examples in (8b) and (10b) illustrate the use of, respectively, mens and ' $n$ mens with the meaning 'human being' and, more specifically, 'man(kind)'. In (12), they both function as a non-referential indefinite and, in (13a) and (14), they may be argued to be vague between a non-referential indefinite and a referential definite interpretation.

(14) Afrikaans

Die geselskap is teen dié tyd gerieflik by mekaar. Piet Poorte en Charlie is al weg. Attie sê: 'Mens moet seker begin dink aan huis toe gaan.'

(Historical Corpus Afrikaans, 2008)

"The company are together comfortably by that time. Piet Poorte and Charlie have already gone. Attie says: 'We/one should probably start thinking of going home."”

Some comments are in order. The ambiguity and infrequency of the referential definite cases, for one, show that this use has not semanticized (yet?) in Afrikaans.

\footnotetext{
${ }^{5}$ Because of the lack of cases of mens vague between 'human being' and a non-referential indefinite interpretation and the infrequency of ambiguity between a non-referential indefinite and a referential definite reading, our chi-squared tests combined the former vague category with 'human being' and the latter with the non-referential indefinite one. No significant differences exist between ' $n$ mens and mens for any period $\left(\chi^{2}=0.08, \mathrm{p}=0.78\right.$ in $1911-1920 ; \chi^{2}=2.80, \mathrm{p}=0.09$ in $1941-1950 ; \chi^{2}=3.02, \mathrm{p}=0.08$ in 1971-1980; $\chi^{2}=1.01, \mathrm{p}=0.31$ in 2001-2010).
} 
The speaker presents a state of affairs that is about themselves, and possibly their addressees, as applying to anyone in the same situation (see Egerland, 2003: 96-99). Examples like (13a) and (14) also attest to the fact that 'man'-pronouns need not have developed a referential indefinite reading to be employed in a referential definite manner (see Giacalone Ramat and Sansò, 2007: 108-109). Another comment concerns the use of ('n) mens as 'human being'. Mens differs from 'n mens in that it can only receive this interpretation when coordinated with God 'God' or dier 'beast', as in (8b). Such cases are constructionally distinct from those of ' $n$ mens, as well as from mens's other uses, and seem unable to give rise to impersonal readings, as indicated by the lack of hits for mens that are vague between 'human being' and a non-referential indefinite interpretation.

Mens's functional range is compared to 'n mens's in Figure 2, in terms of the categories from Figure 1.

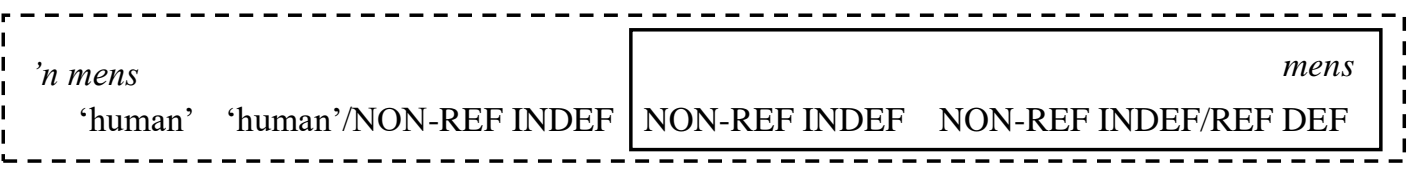

Figure 2. Functional range of ' $n$ mens versus mens.

Excluding attestations like (8b), we can conclude that the more grammaticalized, unambiguously pronominal form mens no longer has its original lexical use as 'human being'. The less grammaticalized form ' $n$ mens, by contrast, still has this meaning, along with the further uses that it shares with mens.

A second observation from Figure 1, already made by Kirsten (2016: 191-192), is that there are no real differences between any periods, for ' $n$ mens and mens separately or together. ${ }^{6}$ ('n) Mens does not appear to have undergone any functional changes in the 20th and 21st centuries. It must have developed into a HIP long before the formal recognition of Afrikaans in 1925. The hits for ' $n$ mens in the Historical Corpus Afrikaans that are vague between 'human being' and a non-referential indefinite reading may nonetheless shed some light on this process, of course. But let us first consider the finding that the 1911-1920 data still contain 43 attestations of Dutch(-like) men (see also Kirsten, 2016: 190). This fact suggests that the development of the new 'man'-pronoun took place when the ancestral one was used as well. A not unusual question to raise then is whether the latter somehow influenced the former. As Figure 3 shows, the answer seems to be negative - at least with respect to their uses.

\footnotetext{
${ }^{6}$ The statistics for mens are $\chi^{2}=0.93, \mathrm{p}=0.33$ for $1911-1920$ vs $1941-1950 ; \chi^{2}=1.65, \mathrm{p}=0.20$ for 1941 1950 vs $1971-1980 ; \chi^{2}=1.56, \mathrm{p}=0.21$ for $1971-1980$ vs 2001-2010. Those for 'n mens are $\chi^{2}=1.00$, $\mathrm{p}=0.32$ for $1911-1920$ vs $1941-1950 ; \chi^{2}=0.49, \mathrm{p}=0.48$ for $1941-1950$ vs $1971-1980 ; \chi^{2}=0.50, \mathrm{p}=0.48$ for 1971-1980 vs 2001-2010. The statistics for mens and 'n mens together are $\chi^{2}=0.06, \mathrm{p}=0.81$ for $1911-1920$ vs $1941-1950 ; \chi^{2}=1.95, \mathrm{p}=0.16$ for $1941-1950$ vs $1971-1980 ; \chi^{2}=2.83, \mathrm{p}=0.09$ for 1971 1980 vs 2001-2010.
} 


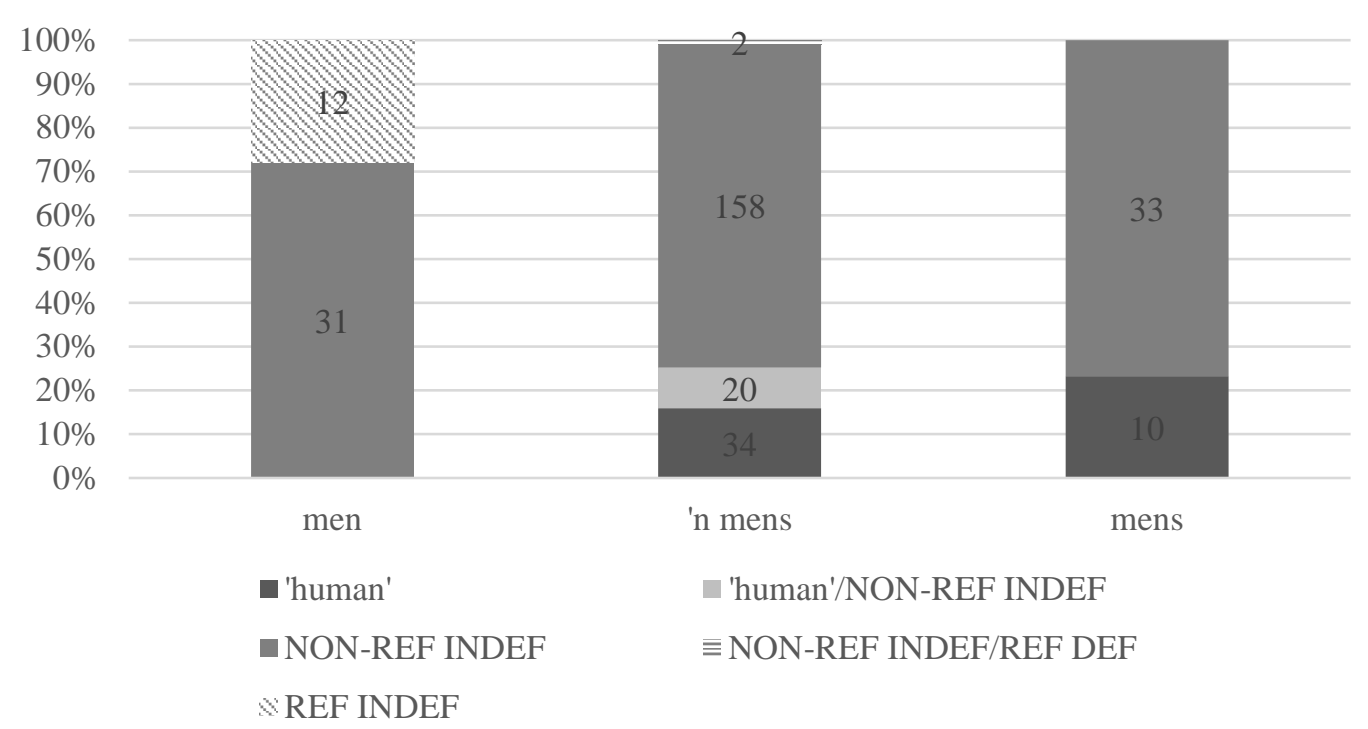

Figure 3. Functional analysis of men and ('n) mens in the 1911-1920 data of the Historical Corpus Afrikaans.

Unlike ('n) mens, fully grammaticalized men has no lexical meaning anymore and can serve not only as a non-referential indefinite, as in (3a), but also as a referential indefinite. This use is illustrated in (15a). It is taken to include cases like (15b) too, in which men combines with a speech act verb to express an evidential meaning.

(15) Afrikaans

a. Men wou hem hier houden tot wonsdag om nog eerst te stemmen.

(Historical Corpus Afrikaans, 1911)

"They wanted to keep him here until Wednesday to still vote first."

b. Men beweert dat de resultaten der wetenskap onfeilbaar zijn. Ik weet nie wie deur die men bedoeld word. (Historical Corpus Afrikaans, 1911)

"They claim that scientific results are infallible. I don't know who "men" is meant to refer to."

In Siewierska and Papastathi's (2011: 604-605) study of third person plural HIPs, such uses are seen as a direct offshoot of the personal use of 'they' unrelated to its other impersonal ones. Their argument is that, in some languages (e.g. Finnish), the third person plural cannot function as a HIP but can be employed in contexts like (15b) and, in others (e.g. German), it exhibits a range of HIP uses but cannot co-occur with speech act verbs to convey evidentiality. Examples like (15b), however, suggest that this use is somehow linked to other impersonal uses, at least for 'man'-pronouns. Gast and van der Auwera (2013: 142) agree but admit: "It is not entirely clear to us whether or not it can be subsumed under one of the other nodes [on our semantic map] ... In our view, this particular use requires more (esp. diachronic) investigation." Such a study falls outside the scope of this article. The differences between ('n) mens and men may point in the right direction, though. The former allows neither a referential indefinite nor a speech act verb reading, as (16) shows, while they are both perfectly acceptable in the latter. 
(16) Afrikaans

a. *('n) Mens wou hom hier hou tot Woensdag.

"They wanted to keep him here until Wednesday."

b. *('n) Mens beweer dat die resultate van die wetenskap onfeilbaar is.

"They claim that scientific results are infallible."

The use in (15b) thus appears to be connected to the referential indefinite one, perhaps unsurprisingly so: the speaker is attributing the assertion that science is infallible to a specific but unknown (set of) individual(s).

In Figure 4, the functional range of men is compared to those of ' $n$ mens and mens, in terms of the categories from Figures 1 and 3.

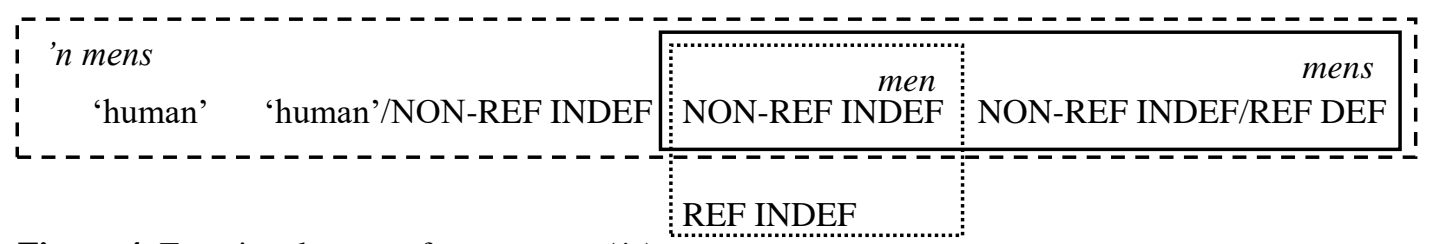

Figure 4. Functional range of men versus ('n) mens.

Given that men has a referential indefinite use and ('n) mens does not, it looks unlikely that the ancestral 'man'-pronoun had an effect on or served as a model for the new one. Supporting evidence for the independent nature of ('n) mens's development comes from the linguistic contexts in which men occurs. As mentioned in Section 1, it tends to be found in texts abounding with Dutch features. It is too simplistic to call the relationship between the two languages before 1925 strictly diglossic but there was a clear trend to employ (a variety close to Present-day) Dutch for formal/official writing while (a variety similar to Present-day) Afrikaans was used in everyday life. Men was therefore probably restricted to situations of use that had little influence on ordinary spoken language and the way it was changing.

To conclude this section, let us have a brief look at the instances of ' $n$ mens ambiguous between 'human being' and a non-referential indefinite interpretation. As Figure 1 makes clear, the percentage of hits that they account for remains relatively stable over time and averages at $11.06 \%$. What they have in common is that they tend to occur in so-called non-assertive contexts. The following attestations are cases in point: the negated possibility in (7), the hypothetical interrogative in (17a) and the negated necessity in (17b).

(17) Afrikaans

a. Hoe sou 'n mens klaar kom sonder om ten minste te kan optel en aftrek?

(Historical Corpus Afrikaans, 1920)

"How would man/one go about without at least being able to add and subtract?"

b. Daar is in werklikheid geen wette wat ' $n$ mens hoef te gehoorsaam nie.

(Historical Corpus Afrikaans, 2002) 
"In reality, there are no laws that man/one needs to obey."

Synchronic ambiguity does not necessarily mirror diachronic changes. The examples in (17), however, support Giacalone Ramat and Sansò's (2007: 101) claim that nonassertive environments form the typical bridging contexts in which 'man' comes to function as a HIP. They argue that, in such environments, it "has the capacity of picking out indiscriminate referents of the class of humans, indicating any individual within a more or less restricted class, which is determined by the [non-assertive] operator itself and may amount to all humanity or to a subgroup thereof, according to the context" (Giacalone Ramat and Sansò, 2007: 108). Thus, it does not seem implausible that it is cases like (17) that gave rise to the impersonal use of ' $n$ mens and eventually to the more grammaticalized form mens. Note also that the importance of such non-assertive contexts for HIPs justifies the reliance on modals, which are non-assertive operators, as a way into the Taalkommissiekorpus and Die Burger data (see Section 2.2).

\subsection{Discussion in light of Dutch}

Figure 4 captures the uses of men in the Historical Corpus Afrikaans but it reflects the functional range of this 'man'-pronoun in Present-day Dutch quite well too. In (18a), Dutch men is shown to no longer allow an interpretation as 'human being'. In (18b) to (18d), examples are given of, respectively, a non-referential indefinite, a referential indefinite and a speech act verb use. Coussé and van der Auwera (2012: 123 ) tentatively add that, like ('n) mens, Dutch men could also receive a referential definite interpretation which is vague with an indefinite one. Our sample of 200 cases of men in ConDiv contains no examples, though. The reason is probably that men is only really employed in formal contexts anymore in Dutch (see Weerman, 2006: 32). This type of language simply does not immediately lend itself to the pragmatic extension of an indefinite item to a definite reading. The absence of this phenomenon in the Historical Corpus Afrikaans may be explained in the same way.

(18) Dutch

a. *Het hoofd van een mens is groter dan de kop van een schaap. Men zou dus meer hersens moeten hebben.

"A human being's head is bigger than a sheep's head. So a human being should have more brains."

b. Als men tegen het slechte vecht ..., veroorzaakt men dan niet tevens het slechte?

(ConDiv)

"If one fights evil ..., does one not cause evil at the same time?"

c. Op de Nicolaas Maesschool, waar het ongeval voor de deur plaatsvond, probeert men de draad weer op te pakken.

(ConDiv)

"At the Nicolaas Maes School, in front of which the accident took place, they are trying to get back to normal again."

d. Men zegt dat Real Madrid nog mooier is maar daar ben ik (nog) nooit geweest.

(ConDiv) 
"They say that Real Madrid is even more beautiful but I have not been there (yet)."

In sum, fully grammaticalized men in Dutch and in 1910s Afrikaans has clearly developed further than ' $n$ mens, which can still be employed lexically, and mens, which cannot serve as a referential indefinite.

An additional distinction needs to be made, though, to describe the (dis)similarities between these 'man'-pronouns. Gast and van der Auwera (2013) split their (quasi-)universal uses up in internal and external ones. In the internal uses, "a 'center of consciousness' ... identifies, or is identified, with the set of referents under discussion" (Gast and van der Auwera, 2013: 139). The speaker of (19a), for instance, may or may not live in Bali themselves but, by employing you, they encourage all interlocutors to put themselves in its inhabitants' shoes. In the external uses, no such identification takes place. In English, this perspective can be expressed by means of they, as in (19b).

(19) a. In Bali, you eat dragonflies.

b. In Bali, they eat dragonflies.

As Gast and van der Auwera (2013: 149) point out, men allows both internal and external interpretations. The Historical Corpus Afrikaans does not contain any relevant attestations but ConDiv does. In (20a), the first chatter's claim with men is clearly understood as having a universal-external reading by the second one: the statement is repeated but with ze 'they'. In (20b), however, the answer to the interviewer's question makes sense only when it is interpreted internally. ('n) Mens, by contrast, is restricted to internal uses, as shown in (20c).

(20) a. Dutch

In Italië eet men ook later, geloof ik ... - In Italië eten ze laat, ja.

(ConDiv)

"In Italy, they also eat later, I think ... - In Italy, they eat late, yes."

b. Dutch

Als u naar China verhuist, spreekt u toch ook Chinees? - Juist, in China spreekt men Chinees.

(ConDiv)

"If you move to China, you'll speak Chinese, right? - 'Yes, in China, one speaks Chinese."

c. Afrikaans

In Italië eet ('n) mens eers laat.

"In Italy, you/*they eat late."

Its functional range in the impersonal domain is, in other words, similar to that of the second person singular (see Gast and van der Auwera, 2013: 146-147).

The last question to be answered here is how ('n) mens compares to een mens functionally. Our sample of 200 cases of een mens in ConDiv reveals the following (dis)similarities. First, like ' $n$ mens but unlike mens, een mens can still be employed 
lexically, as in (21a). Second, it resembles ('n) mens in that it can serve as a nonreferential indefinite, as (21b) shows. Third, like ('n) mens, it is also occasionally used to convey some kind of referential definite meaning. In (21c), for instance, the speaker essentially wants to express that they have read about it but present their own experience as somehow applicable to everyone.

(21) Dutch

a. Een mens is soms net als een hond.

(ConDiv)

"Sometimes, a human is just like a dog."

b. Voor Parren is de uitspraak van de rechter een bevestiging ... dat de aanschaf van boeken de beste investering is die een mens kan doen.

(ConDiv)

"For Parren, the judge's decision is confirmation ... that the acquisition of books is the best investment that one/a human being can make."

c. Hoe ik dat weet? Ach een mens leest wel eens wat.

(ConDiv)

"How do I know that? Well, you/I/a human being read/s stuff sometimes."

Fourth, and lastly, een mens is similar to ('n) mens in not having any universalexternal, referential indefinite and speech act verb uses. The unacceptability of (22) can serve as an example.

\section{Dutch \\ *In Italië eet een mens laat. \\ "In Italy, they eat late."}

In short, ('n) mens and een mens have more or less the same functional potential. The main difference between the two lies in their levels of grammaticalization. Een mens is still an indefinite singular NP: its article is compulsory, it cannot combine with a marker of plurality like elkaar 'each other' and needs to be referred back to by third person singular masculine hij (see Section 1). The result is that een mens always remains interpretable as 'a human being'.

\subsection{First interim conclusion}

('n) Mens, men and een mens have been shown to share the non-referential indefinite use (possibly ambiguous with a referential definite interpretation). These forms have also been found to differ in a number of respects. Unlike more grammaticalized mens and men, 'n mens and een mens can still be employed lexically, for instance. The potential vagueness of ('n) mens between 'human being' and a non-referential indefinite reading has been argued to be a plausible reflection of the development of ('n) mens into a HIP. In addition, in contrast to ('n) mens and een mens, men accepts not only an internal but also an external interpretation in its non-referential use and can function as a referential indefinite (including the speech act verb use here). Finally, these differences have been argued to make it unlikely that men had much 
influence on the emergence of ('n) mens.

\section{Formal analysis}

\section{1 'n Mens versus mens}

To answer the question whether mens gains ground on ' $n$ mens, Figure 5 presents the frequencies per 10,000 words of both forms as unambiguous HIPs (and of men) from 1911 to 2010.

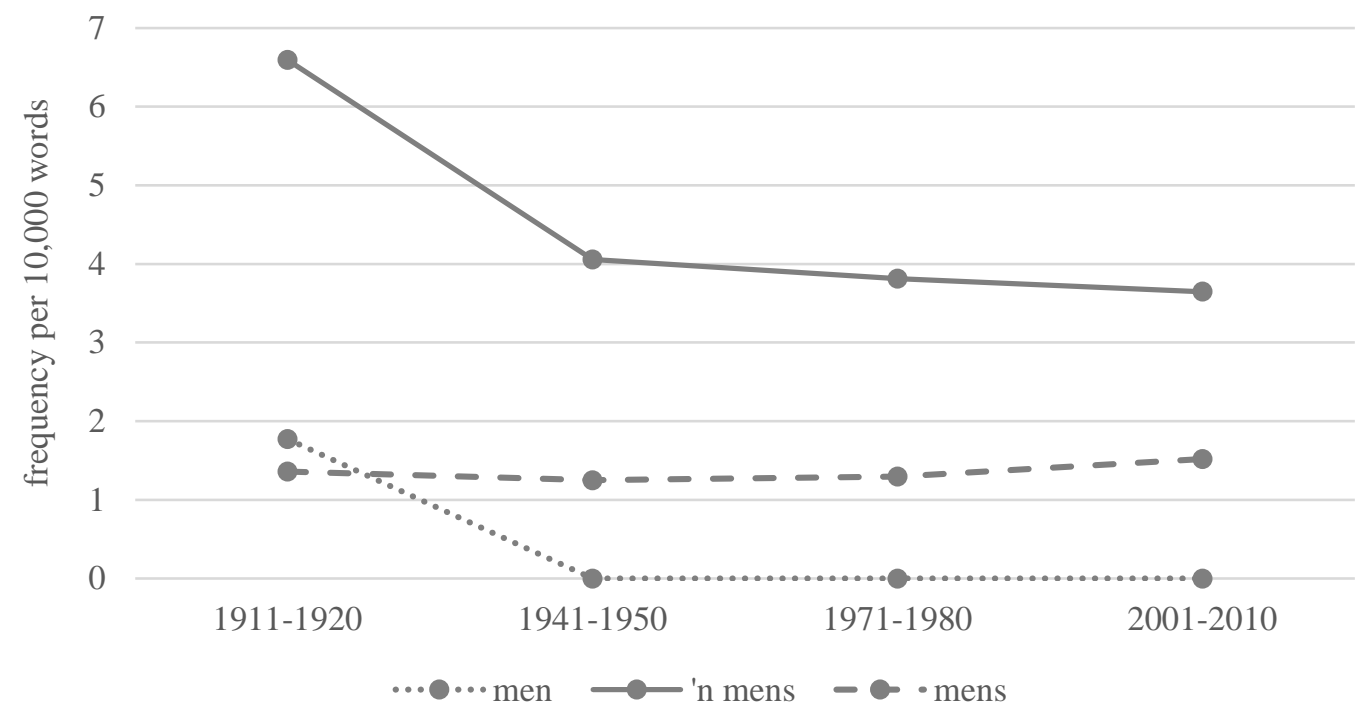

Figure 5. Relative frequency of ' $n$ mens, mens and men as unambiguous HIPs in the Historical Corpus Afrikaans.

Men clearly disappears from the corpus after 1911-1920. Mens's rate of occurrence, though at its highest in 2001-2010, does not vary greatly. ${ }^{7}$ The use of ' $n$ mens exhibits a substantial drop from 1911-1920 to 1941-1950 but is fairly stable afterward, despite being at its lowest in 2001-2010. ${ }^{8}$ In sum, the frequency of (' $n$ ) mens does not appear to have changed much over the years.

To truly capture the choice between the two forms for the expression of impersonalization, Figure 6 gives a proportional picture of the Figure 5 data.' $n$ Mens is shown to be the most popular option by far. There seems to be a gradual rise in the

\footnotetext{
${ }^{7}$ Kendall's tau correlation test reveals no significant link between changing rate of occurrence and "increasing" time $(\tau=0.33, p=0.75)$. Our log-likelihood tests do not show any significant differences between any periods either $\left(G^{2}=0.12, p>0.05\right.$ for $1911-1920$ vs $1941-1950 ; G^{2}=0.02, p>0.05$ for 1941 1950 vs $1971-1980 ; \mathrm{G}^{2}=0.47$, $\mathrm{p}>0.05$ for $1971-1980$ vs $2001-2010$ ).

${ }^{8}$ Log-likelihood tests confirm that the only significant difference between subsequent periods is that between 1911-1920 and 1941-1950: $\mathrm{G}^{2}=15.49, \mathrm{p}<0.01\left(\mathrm{G}^{2}=0.20, \mathrm{p}>0.05\right.$ for 1941-1950 vs 1971-1980; $\mathrm{G}^{2}=0.10, \mathrm{p}>0.05$ for $1971-1980$ vs 2001-2010). There is also strong negative correlation between relative frequency and time which is, however, not significant $(\tau=-1, \mathrm{p}=0.08)$.
} 
selection of mens, however. ${ }^{9}$ We conclude, with Kirsten (2016: 192 in translation), that "there appears to be an increasing tendency to leave out ' $n$."

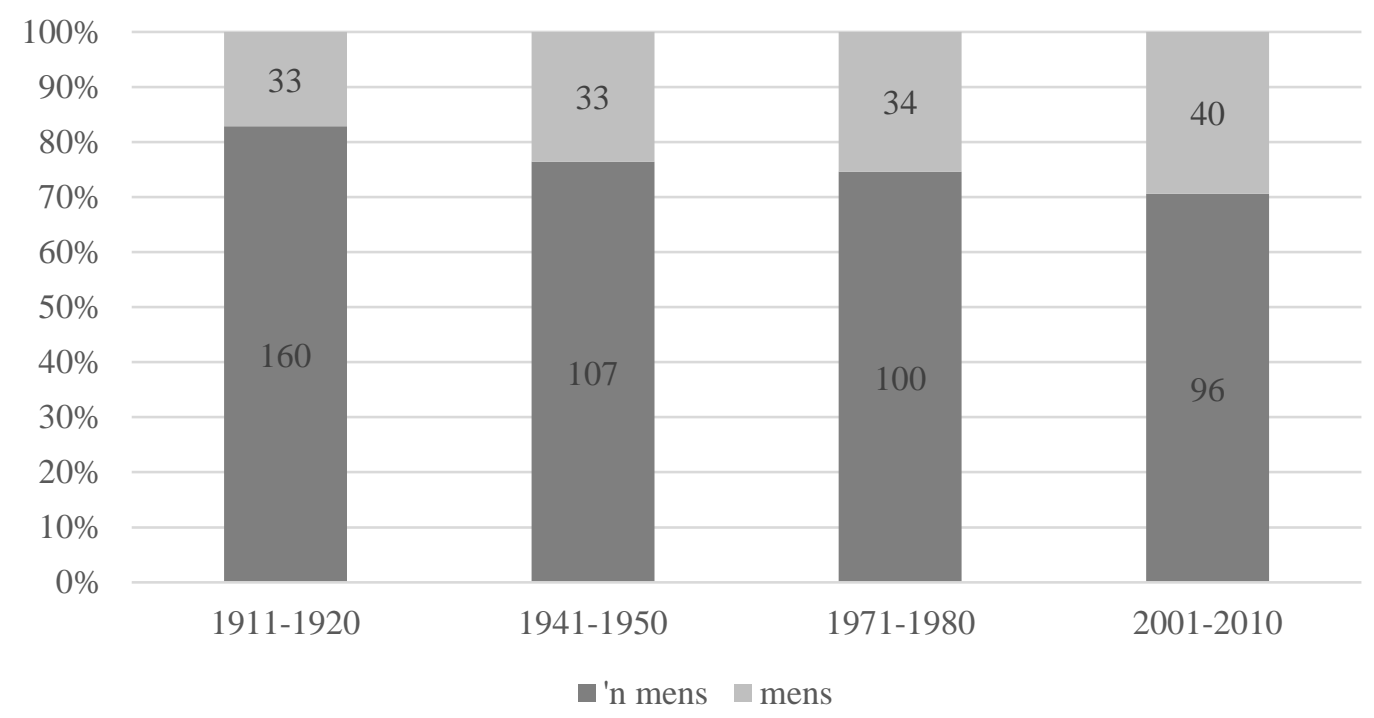

Figure 6. Proportions of ' $n$ mens and mens as unambiguous HIPs in the Historical Corpus Afrikaans.

This trend in the Historical Corpus Afrikaans is corroborated by the Die Burger Corpus. In the 1990 newspaper articles, mens makes up 4.15\% of the 1420 attestations of ('n) mens. Its share rises to $8.92 \%$ of the 2556 hits in the articles from $2000 .^{10}$

To anyone familiar with Present-day Spoken Afrikaans, it may be surprising that the use of mens in the aforementioned corpora is still quite limited. It is tempting to attribute this phenomenon to some prescriptive pressure to employ ' $n$ mens instead but Kirsten (2016: 192-193) convincingly argues that prescriptivism probably does not a play a huge role. Her survey of the 20th- and 21st-century normative literature on Afrikaans reveals that "most sources are comfortable with either of the two forms" (Kirsten 2016: 192 in translation). To check the possible impact of editing, she also compares the use of mens in unpublished versus published material in the Historical Corpus Afrikaans. The unpublished material displays a strong continuous increase from 1911 to 2010 but, from 1971 to 2010, the published material too displays a distinctive rise. Kirsten (2016: 193 in translation) therefore concludes: "It seems that, if there were any editorial intervention, it has decreased or perhaps even stopped by the last period."

The limited use of mens in our corpora, compared intuitively to speech, is therefore likely due to the fact that written language tends to be somewhat more conservative (see Kirsten, 2016: 192 too). This is not the whole story, however, as a quick look at the Taalkommissiekorpus shows. Figure 7 presents the proportions of mens and ' $n$ mens in the various subcorpora and in the corpus as a whole.

\footnotetext{
${ }^{9}$ No real differences exist between subsequent periods but the distribution in 1911-1920 differs significantly from that in 2001-2010: $\chi^{2}=6.31, \mathrm{p}=0.01 \quad\left(\chi^{2}=2.14, \mathrm{p}=0.14\right.$ for 1911-1920 vs 1941-1950; $\chi^{2}=0.12, \mathrm{p}=0.73$ for $1941-1950$ vs $1971-1980 ; \chi^{2}=0.55, \mathrm{p}=0.46$ for $1971-1980$ vs $2001-2010$ ).

${ }^{10}$ The difference is statistically significant: $\chi^{2}=30.95, p=0.01$.
} 


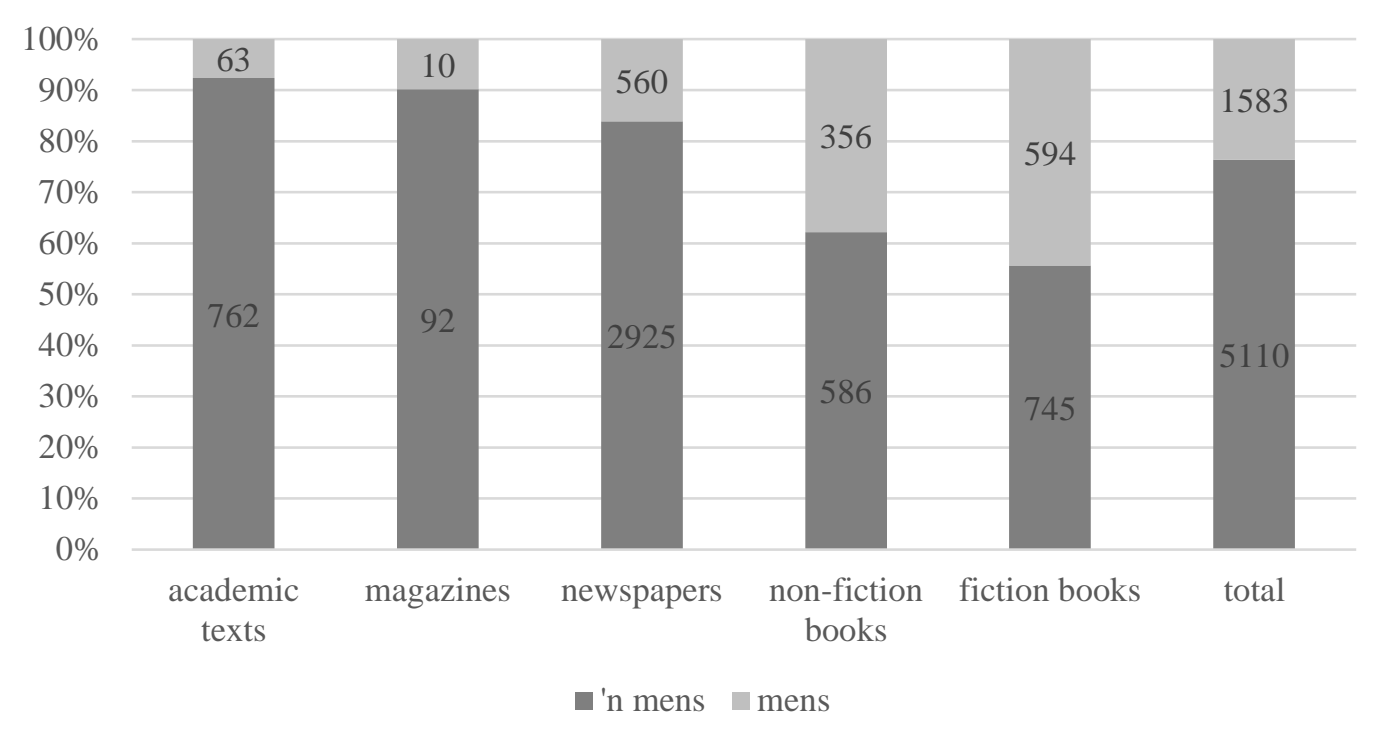

Figure 7. Proportions of 'n mens and mens in the Taalkommissiekorpus.

The results suggest that additional factors are at play. ${ }^{11}$ In academic texts, ' $n$ mens is clearly preferred, significantly more so than in all other genres except for magazines. This difference raises the question whether a genre's formality affects the choice between the two forms. Another interesting finding is that mens is substantially more prevalent in non-fiction and even more so in fiction. Especially this last result may stem from the fact that fiction contains more informal, speech-like language (e.g. in dialogues). We leave it for further research, though, to examine the impact of such factors in detail. Let it suffice here to say that the non-fiction and fiction subcorpora in Figure 7 indicate that mens's actual use in Present-Day Afrikaans is more prolific than the Historical Corpus Afrikaans and the Die Burger Corpus suggest.

\subsection{Suppletion}

As mentioned in Section 3.1, ('n) mens as a HIP is said to require second person singular suppletive forms for its corresponding possessives and reflexives and for the expression of a second subject or object HIP in the same sentence. Jou 'yourself' and $j y$ 'you' in (23) can serve as examples.

\section{(23) Afrikaans}

'n Mens kon jou verbeel jy sien die geel poeierkwassies aan die doringbome verlep.

(Historical Corpus Afrikaans, 2006)

"One can imagine that one sees the yellow blossoms on the thorn trees wilt."

Dutch men, by contrast, relies on third person singular masculine possessive and

\footnotetext{
${ }^{11}$ The statistics are $\chi^{2}=0.59, \mathrm{p}=0.44$ for academic vs magazines; $\chi^{2}=38.36, \mathrm{p}<0.001$ for academic vs newspapers; $\chi^{2}=221.09, \mathrm{p}<0.001$ for academic vs non-fiction; $\chi^{2}=325.64, \mathrm{p}<0.001$ for academic vs fiction; $\chi^{2}=2.91, \mathrm{p}=0.09$ for magazines vs newspapers; $\chi^{2}=31.67, \mathrm{p}=0.01$ for magazines vs fiction; $\chi^{2}=46.49, \mathrm{p}<0.001$ for magazines vs fiction; $\chi^{2}=231.25, \mathrm{p}<0.001$ for newspapers vs non-fiction; $\chi^{2}=425.47, \mathrm{p}<0.001$ for newspapers vs fiction; $\chi^{2}=9.82, \mathrm{p}=0.01$ for non-fiction vs fiction.
} 
reflexive forms and can be repeated as a subject in the same clause, as zich 'himself' and the second men in (24a) show. ${ }^{12}$ It also possesses no suppletive object forms. A sentence like (24b), with a 'man'-pronoun subject and an impersonal object next, is not grammatical in Dutch. The subject needs to be turned into a second person singular, as Draye (2014: 242) makes clear with (24c).

(24) a. Dutch

Als men zich serieus zorgen maakt om het bestaan, bedrijft men geen politiek.

(ConDiv)

"If one seriously worries oneself about existence, one does not do politics."

b. Afrikaans

Mens weet nooit regtig wat hulle jou gaan vra nie.

"You never know what they will ask you."

c. Dutch

$J e / * m e n$ weet maar nooit wat ze je zullen vragen.

(Draye, 2014: 242)

"You never know what they will ask you."

Een mens, as a masculine noun, makes use of the same possessives and reflexives as men, as (25a) shows. It differs from ('n) mens as a HIP in this respect. It differs from men too, in its inability to be repeated as a subject in the same clause, as (25b) and (25c) show.

(25) Dutch

a. Mag een mens dan niet leren van zijn fouten?

(ConDiv)

"Can a human being/one then not learn from his/one's mistakes?"

b. Een mens kan alles, als hij maar wil.

(ConDiv)

"Man can do anything if he wants to."

c. ?Een mens kan alles, als een mens maar wil.

"Man can do anything if he wants to."

The repetition in (25c) sounds odd and does not occur in our sample of 200 instances. In the attested pattern in (25b), een mens behaves like any indefinite NP: it is referred back to by the appropriate personal pronoun hij.

It is well-known that, cross-linguistically, second person singular HIPs tend to be limited to universal-internal contexts (Gast and van der Auwera, 2013: 146-147). Afrikaans $j y / j o u$ is no exception. It is therefore not unreasonable to ask: is the fact that, unlike Dutch men, ('n) mens uses those pronominal forms for suppletion linked to its restriction to the same contexts? To answer the question, let us consider German man. On the one hand, like ('n) mens, it has suppletive object forms, though it relies

\footnotetext{
${ }^{12}$ Strictly speaking, zich is gender- and number-neutral. The possessive is unmistakably third person singular masculine, though: zijn 'his'.
} 
on 'one' rather than the second person singular. Accusative einen 'one' in (26a) is a case point. Interestingly, HIPs derived from 'one' typically serve universal-internal purposes only too (Gast and van der Auwera, 2013: 145-146). Einen is no different, as the unacceptability of (26b) with a referential indefinite interpretation demonstrates. Yet, man is perfectly fine as a referential indefinite in (26c) - as long as no suppletive forms of 'one' are present.

(26) German

a. Man weiß ja nie, was die einen fragen.

(Draye, 2014: 242)

"You never know what they will ask you."

b. *Ich habe einen auf/an der Strasse arbeiten hören. $\quad$ (Fenger, 2016: 9) "I heard someone work on the road."

c. Man hat schon wieder die Steuern erhöht.

(Gast and van der Auwera, 2013: 144)

"They have raised the taxes again."

On the other hand, like Dutch men, man can be repeated as a subject in the same sentence and uses third person singular masculine possessives and reflexives, as in (27a). As Cabredo Hofherr (2010: 10) points out with (27b), these suppletive forms also appear in non-referential indefinite contexts only and block a referential indefinite reading, which is possible otherwise.

(27) German

a. Man kann sein Auto hier nicht parken. $\quad$ (Cabredo Hohferr, 2010: 7)

"One cannot park one's car here."

b. *Heute morgen hat man seine Adresse für dich hinterlassen.

(Cabredo Hohferr, 2010: 10)

"This morning, someone left their address for you."

In short, German suggests that suppletive forms have little effect on a 'man'pronoun's functional range: they do not seem to be tolerated in referential indefinite contexts anyway. So the fact that ('n) mens, unlike men, has not (yet) evolved beyond a non-referential indefinite use should not be attributed to its second person singular suppletive forms.

The suppletion principles sketched at the beginning of this section describe the usage facts of Afrikaans quite well. However, in $7.80 \%$ of the 141 situations where they should apply in the Historical Corpus Afrikaans, ('n) mens is used instead of the second person singular, mostly as a repeated subject but occasionally also as a possessive, as in (28a) and (28b). No reflexive form of ('n) mens is found in the Historical Corpus Afrikaans but it does occur (very infrequently) in the Taalkommissiekorpus, as (28c) shows.

(28) Afrikaans

a. Wanneer mens die jubileum-artiekels in hierdie jaarboek lees kan mens 
dit ook maklik verstaan.

(Historical Corpus Afrikaans, 1920)

"If one reads the anniversary articles in this yearbook, one can also easily understand this."

b. Dr Nikolic stel voor dat mens slegs die boonste deel van die gesig met Botox behandel ..., anders lyk mens se gesig te styf en uitdrukkingloos.

(Historical Corpus Afrikaans, 2010)

"Dr Nikolic suggests that one treats only the upper part of the face with Botox ..., otherwise one's face looks too stiff and expressionless."

c. ... hoe mens mensself moet handhaaf in 'n werksituasie.

(Taalkommissiekorpus)

"... how one should maintain oneself in a work situation."

Unfortunately, our data do not allow us to assess how widespread/acceptable this analogical extension of mens to typically suppletive slots is in informal/spoken language, whether it is on the rise or whether there is any influence from English one, one's and oneself. Let it suffice here to say that this phenomenon is not a brand-new development: (28a) is one of three examples in the Historical Corpus Afrikaans's 1911-1920 component.

\subsection{Syntactic functions}

Men is known to be limited to the function of subject (e.g. Draye, 2014: 242). The Afrikaans 'man'-pronoun is more flexible syntactically. In $92.51 \%$ of the HIP instances of ('n) mens in the Historical Corpus Afrikaans, it does act as the subject of the sentence but it is also found to occur as an object, as a possessive with no previous mention of the pronoun in the sentence and even in prepositional phrases, as in (29a) to $(29 \mathrm{c})$.

(29) Afrikaans

a. ... dat dit mens in staat stel om 'n hele elektromagnetiese spektrum ... as 'n funksie vas te lê.

(Historical Corpus Afrikaans, 2007)

"... that it enables one to capture an entire electromagnetic spectrum as a function."

b. Hoe die waarheid soms wonderliker kan wees dan die wildste vlugte van mens s' $n$ verbeelding, ...

(Historical Corpus Afrikaans, 1920)

"How the truth can sometimes be more wonderful than the wildest stretches of one's imagination ..."

c. As daar so iets met mens gebeur kyk jy ook weer na die lewe met ander oё.

(Historical Corpus Afrikaans, 1980)

"If something like that happens to you, you look at life differently again."

As (30) shows, een mens is like ('n) mens in having the ability to appear as a nonsubject. 
(30)

Dutch

We worden niet serieus genomen ... Dat is het ergste wat een mens kan overkomen.

(ConDiv)

"We're not taken seriously ... That's the worst thing that can happen to a human being/you."

This difference in flexibility reflects the degree of grammaticalization of ('n) mens and een mens versus men. As Egerland (2003: 92) argues, items with only a nonreferential indefinite interpretation can occur as subjects and objects while items with non-referential as well as referential indefinite uses can only function as subjects. ('n) Mens and een mens are instances of the former, men one of the latter. Egerland's (2003: 92-93) formalist account is paraphrased by Giacalone Ramat and Sansò (2007: 113-114): "Pronouns in object positions are possible only if they maintain some informational content allowing the identifiability of their intended referent (even in very general terms)." The more a 'man'-pronoun grammaticalizes, the more bleached its semantic content becomes, of course, and the less likely it serves as a non-subject.

\subsection{Second interim conclusion}

It has been shown, in line with Kirsten (2016: 192), that ('n) mens has not undergone any dramatic changes in frequency in recent times but that mens has still gained ground on ' $n$ mens. Following Kirsten (2016: 192-193), the limited use of mens in our data has been attributed not to any prescriptive prejudice against the form but to written language being more conservative than speech. In addition, ('n) mens has been found to rely on second person singular suppletive forms in a large majority of the cases (the use of forms like mens se instead is rare but goes back to at least the 1910s). Afrikaans and Dutch differ in this regard. Not only do Dutch men and een mens use third person singular masculine possessives and reflexives, the latter can also easily be repeated as a subject (unlike the former) and lacks a suppletive object form. It has been argued, though, that suppletion by the second person singular cannot explain why ('n) mens only has universal-internal uses. Lastly, ('n) mens and een mens have been shown to be able to occur in syntactic functions other than the subject, unlike men. This dissimilarity can be ascribed to their respective levels of grammaticalization.

\section{Conclusion}

Four of the five questions raised in Section 1 have already been answered, in the interim conclusions in Sections 3.3 and 4.4. Those results will inform our present discussion of the final question, i.e. how do ('n) mens and men compare to other 'man'-pronouns? Let us first stress, though, that Afrikaans is a typical Germanic language in having a 'man'-pronoun. Within Germanic, only English does not have one (anymore) (see Giacalone Ramat and Sansò, 2007: 124).

As to meaning, Dutch men is similar to the 'man'-pronouns in, inter alia, German and Swedish, in allowing both non-referential and referential indefinite 
interpretations. Afrikaans ('n) mens resembles those in, inter alia, Frisian and Icelandic: they all exclude universal-external and referential indefinite readings (see Fenger, 2016: 3). Yet, the difference is that Frisian men, for instance, is more grammaticalized than ('n) mens formally. For one, there is no optional article in Frisian. The implication for Afrikaans is that even if/when mens becomes a fullfledged HIP and permanently loses its article, it need not develop a referential indefinite meaning or be restricted to subjecthood like Dutch men. Frisian men does not have those properties either (see Hoekstra, 2010). Another functional dissimilarity of both ('n) mens and men to certain other 'man'-pronouns concerns their referential definite interpretation. In Afrikaans and Dutch, it is a fairly infrequent, pragmatic extension of the non-referential indefinite use. By contrast, Swedish, for instance, is known to have a well-established first person singular use of man (see Coussé and van der Auwera, 2012: 122).

As to form, men behaves like other potentially referential indefinite 'man'pronouns in being limited to subjecthood (see Draye, 2014: 242 on German) and ('n) mens like other non-referential indefinite HIPs in not having this limitation (see Egerland, 2003: 91 on Icelandic). As regards suppletion, though, both Dutch and Afrikaans are quite unique within Germanic. According to Fenger (2016: 21), men is the only 'man'-pronoun that has no corresponding object form. Most other Germanic languages rely on 'one' for this. Moreover, the 'man'-pronoun in Germanic is typically followed by possessive and reflexive forms of the third person singular masculine (see Fenger, 2016: 15 on German) or 'one' (see Hoekstra, 2010: 36 on Frisian). Afrikaans, however, draws on the second person singular. Further research is needed to see how these peculiarities of ('n) mens and men arose.

\section{References}

Cabredo Hofherr, P. 2010. Binding Properties of Impersonal Human Pronouns in Generic and Episodic Contexts. Available at http://archive.sfl.cnrs.fr/sites/sfl/IMG/pdf/impersMay2010Cabr edoHofherrManOnLa.pdf [last accessed on 6 April 2017].

Conradie, C.J. 2017. Root Semantics. Taalportaal. Available at http://taalportaal.org/taalportaal/topic/pid/topic14857881438688606 [last accessed on 4 October 2017].

Coussé, E. and van der Auwera, J. 2012. Human Impersonal Pronouns in Swedish and Dutch: a Contrastive Study of Man and Men. Languages in Contrast 12(2):121-138.

De Smet, H. n.d. Die Burger Corpus. Leuven: Leuven University.

Donaldson B.C. 1993. A Grammar of Afrikaans. Berlin: De Gruyter.

Draye, L. 2014. Man en men: een Wereld van Verschil. In Patroon en Argument, F. Van de Velde, H. Smessaert, F. Van Eynde and S. Verbrugge (eds), 241-253. Leuven: Leuven University Press.

Egerland, V. 2003. Impersonal Pronouns in Scandinavian and Romance. Working Papers in Scandinavian Syntax 71:75-102.

Fenger, P. 2016. How Impersonal does One Get? A Study of Man-Pronouns in Germanic. Available at https://ling.auf.net/lingbuzz/002802 [last accessed on 6 April 2017].

Gast, V. and van der Auwera, J. 2013. Towards a Distributional Typology of Human 
Impersonal Pronouns, Based on Data from European Languages. In Languages Across Boundaries, D. Bakker and M. Haspelmath (eds), 119-158. Berlin: De Gruyter.

Giacalone Ramat, A. and Sansò, A. 2007. The Spread and Decline of Indefinite ManConstructions in European Languages: an Areal Perspective. In Europe and the Mediterranean Linguistic Areas, P. Ramat and E. Roma (eds), 95-131. Amsterdam: Benjamins.

Gries, S.Th. 2013. Elementary Statistical Testing with R. In Research Methods in Language Variation and Change, M.G. Krug and J. Schlüter (eds), 361-381. Cambridge: Cambridge University Press.

Grondelaers, S., Deygers, K., Van Aken, H., Van Den Heede, V. and Speelman, D. 2000. Het ConDiv-Corpus Geschreven Nederlands. Nederlandse Taalkunde 5(4):356-363.

Hoekstra, J. 2010. On the Impersonal Pronoun Men in Modern West Frisian. Journal of Comparative Germanic Linguistics 13(1):35-64.

Kirsten, J. 2016. Grammatikale Verandering in Afrikaans van 1911-2010. PhD dissertation, North-West University Vanderbijlpark.

Rayson, P.E. and Garside, R. 2000. Comparing Corpora Using Frequency Profiling. Proceedings of the Association for Computational Linguistics Workshop on Comparing Corpora at their 38th Annual Meeting. Hong Kong, China, 7 October 2000. Association for Computational Linguistics. 1-6.

Siewierska, A. and Papastathi, M. 2011. Towards a Typology of Third Personal Plural Impersonals. Linguistics 49(3):575-610.

Taalkommissie. 2010. Taalkommissiekorpus. Pretoria: Suid-Afrikaanse Akademie vir Wetenskap en Kuns.

Weerman, F. 2006. It's the Economy, Stupid: een Vergelijkende Blik op Men en Man. In Nederlands tussen Duits en Engels, M. Hüning, U. Vogl, T. van der Wouden and A. Verhagen (eds), 19-47. Leiden: Stichting Neerlandistiek Leiden.

Author's address

Daniël Van Olmen

Department of Linguistics and English Language

Lancaster University

County South C68

Bailrigg

LA1 4YW Lancaster

United Kingdom

d.vanolmen@lancaster.ac.uk 